\title{
Patterns of early cohort development following shelterwood cutting in three Adirondack northern hardwood stands
}

\author{
David G. Ray*, Ralph D. Nyland, Ruth D. Yanai \\ State University of New York, College of Environmental Science and Forestry, Syracuse, NY 13210, USA
}

Received 19 December 1997; accepted 6 October 1998

\begin{abstract}
Remeasurement and chronosequence techniques were used to describe early development in three Adirondack northern hardwood stands for up to 26 years following shelterwood seed cutting to 35-65\% canopy cover. Earlier herbicide treatments had controlled dense American beech (Fagus grandifolia) understories in the stands, leaving them devoid of advance regeneration. Deer (Odocoileus virginianus borealis) had also been reduced by hunting and through natural losses. Findings showed that total stems (stems $\geq 0.3 \mathrm{~m}$ tall) and saplings (stems $\geq 2.54 \mathrm{~cm} \mathrm{DBH}$ ) followed distinct patterns of development among the stands. Total stems peaked around five years after seed cutting, suggesting that most new individuals had initiated by that time. By 10 years total stems were declining substantially, indicating that crown closure had occurred and growing space was becoming limiting within the new cohort. By 19 years sapling abundance had peaked, and by 26 years numbers had begun to decline. Non-linear regression techniques were used to model consistent patterns of development among the stands. Observed patterns of self-thinning were related to the timing of canopy closure and subsequent stratification within the new cohort. (C) 1999 Elsevier Science B.V. All rights reserved.
\end{abstract}

Keywords: Northern hardwoods; Natural regeneration; Self-thinning; Stand dynamics

\section{Introduction}

The regeneration period has been described as the most dynamic and critical time in the development of a new age class (Hibbs, 1983; Marquis, 1987). For that reason, much regeneration research in northern hardwoods has focused on determining the threshold levels of early stocking required to ensure success, with particular emphasis on even-aged reproduction methods (Marquis, 1987). Development of these criteria

*Corresponding author. has generally been driven by concerns related to species composition, the spatial distribution and number of stems, the status of interfering vegetation, and potential losses to herbivory. In most cases the research has focused on the first decade following a regeneration treatment, with limited attempts to describe the later condition of the developing cohort. As a result, there is a general lack of information detailing early patterns of development following even-aged reproduction method cutting in northern hardwoods. In contrast, stand development is well documented beyond $40-60$ years when cultural treat- 
ments become feasible (Roach and Gingrich, 1968; Leak et al., 1969; Marquis et al., 1984). A better understanding of the entire process of cohort development in these northern hardwood communities will require consideration of both early and intermediate stages.

Although the earliest stages of cohort development appear chaotic, some degree of order becomes increasingly apparent as these stands move into the aggradation (Bormann and Likens, 1979) or stem exclusion (Oliver, 1981) phase of development. Total numbers of stems decline as stand biomass increases. Differing growth rates of component species can significantly affect structural attributes of an emerging community (Hibbs, 1983; Wang and Nyland, 1993), as can the spatial arrangement and initial height of any advance regeneration (Wang and Nyland, 1993; Oliver and Larson, 1996). These features must be taken into consideration when evaluating patterns of cohort development.

Kelty and Nyland (1981) used a chronosequence approach to describe regeneration development through 11 years in six Adirondack stands that received shelterwood seed cuts. Consistent with earlier work, their findings demonstrated the benefit of understory beech control and a concurrent reduction of deer browsing pressure for regenerating diverse and commercially desirable stands (Tierson, 1967; Richards and Farnsworth, 1971).

Although past research has provided conceptual models of even-aged stand development (Bormann and Likens, 1979; Oliver, 1981), patterns of early cohort development have not yet been fully described based upon empirical evidence. Both Kelty (1987) and Hannah (1988) summarized available regeneration data following shelterwood seed cutting in northern hardwoods. The research reported here sought to: (1) determine whether there was a discernible pattern of development among these Adirondack northern hardwood stands following shelterwood seed cutting preceded by understory beech control and reduced deer browsing pressure; (2) develop regression models describing the composite of the remeasurement and chronosequence regeneration data that might depict a consistent developmental pattern; and (3) provide continuity to the existing description of stand development in even-aged northern hardwoods.

\section{Methods}

\subsection{Study area}

We studied three shelterwood stands located on the Archer and Anna Huntington Wildlife Forest at Newcomb, New York, in Hamilton and Essex counties in the central Adirondack Mountains (latitude $44^{\circ} 0^{\prime} \mathrm{N}$, longitude $72^{\circ} 15^{\prime} \mathrm{W}$ ). Local climate is cool and moist with a mean annual temperature of $6^{\circ} \mathrm{C}$ (January mean of $-9^{\circ} \mathrm{C}$ and a July mean of $19^{\circ} \mathrm{C}$ ). Precipitation occurs evenly throughout the year and averages $101.6 \mathrm{~cm}$, with $250-500 \mathrm{~cm}$ of snow. The mean annual frost-free period is 122 days.

Soils on the property are of glacial till origin, variable in depth, and patchy in distribution. Soils on the mid-slope hardwood-dominated sites described in this study were Typic Haplorthods, occurring within Becket mapping units, consisting typically of deep, moderately well-drained, strongly acid, moderately coarse textured soils with a fragipan (Simon, 1979).

Northern hardwood communities dominate the better drained mid-slope sites on the Huntington Wildlife Forest. Sugar maple (Acer saccharum), American beech, and yellow birch (Betula alleghaniensis) occur in variable proportions, but collectively comprise the majority of basal area. Common associates include white ash (Fraxinus americana), red maple (Acer rubrum), black cherry (Prunus serotina), American basswood (Tilia americana), American elm (Ulmus americana), white birch (Betula papyrifera), and bigtooth (Populus grandidentata) and quaking (Populus tremuloides Michx.) aspens. Red spruce (Picea rubens), balsam fir (Abies balsamea), white pine (Pinus strobus) and hemlock (Tsuga canadensis) occur as scattered individuals in these stands. The stands used for the study reported here had this initial composition, but the cuttings primarily left sugar maple as seed trees.

The uneven-aged structure of the 'old-growth' (softwoods, largely red spruce and eastern hemlock, were removed from these stands in the late 1800s, otherwise they were unmanaged) communities has favored the development of shade-tolerant understory vegetation (beech and sugar maple) over time (Sage, 1983). While sugar maple is numerous in the smaller size classes (up to $123550 / \mathrm{ha}<0.5 \mathrm{~m}$ tall), beech typically accounts for $70-95 \%$ of the larger understory 
stems (1975 to 3460/ha), often forming distinct subcanopies between 2 and $7.5 \mathrm{~m}$ in height. The understory dominance of beech has been attributed to a combination of factors. Beech is extremely shadetolerant and overstory conditions in these stands are suitable for its development. Its prevalent regeneration mechanism of root suckering aids in its proliferation. Also, deer do not browse intensively on beech. Over time it has become the principal understory species on hardwood sites throughout much of the central Adirondacks (personal observation).

\subsection{Control of beech and herbivory}

A combination of herbicide treatments and deer density regulation have proven necessary to control the dense understories and effectively regenerate diverse and commercially viable stands on the Huntington Wildlife Forest (Tierson, 1967; Richards and Farnsworth, 1971; Kelty and Nyland, 1981). The treatments must precede any reproduction method cutting. Therefore, site preparation included understory mistblowing with $2,4,5-\mathrm{T}$ prior to seed cutting to eliminate existing woody vegetation to heights of 4.5$6 \mathrm{~m}$ from each of the study sites. Remaining understory beech $2.54-20 \mathrm{~cm}$ DBH were killed by individual stem treatment. Although 2,4,5-T is no longer available for commercial application, similar effects have been achieved using glyphosate (Roundup) and triclopyr (Garlon) for controlling beech understories in the Northeast (Ostrofsky and McCormack, 1986; Horsley, 1994). Beech stems of merchantable size $(>20 \mathrm{~cm})$ were removed during seed cutting operations, effectively eliminating this species as a residual tree (Kelty, 1979; Sage, 1983). As a result of these treatments, the three study sites lacked both residual understory trees and advance regeneration at the time of seed cutting.

Deer population density was estimated at 10 animals $/ \mathrm{km}^{2}$ on the Huntington Wildlife Forest in 1966. At that level, it essentially precluded the establishment of desirable regeneration (Kelty, 1979). Controlled hunts on the northern half of the property between 1967 and 1969 reduced the density to 5 animals $/ \mathrm{km}^{2}$. No further hunting occurred during the regeneration period of the three shelterwood stands discussed here (last seed cutting completed in 1979). Yet deer populations remained between 5 and 6 animals $/ \mathrm{km}^{2}$ through 1978 , probably because periodic harsh winters maintained these population levels.

\subsection{The shelterwood stands}

Stand I is 14 ha and was sampled at 4, 5, 7, 9, and 16 years following seed cutting. Seed cutting began during the summer and extended through the winter of 1979. Seed trees consisted largely of sugar maple with a residual canopy cover of $\approx 35 \%$ at four years after treatment. At that time, the stand averaged 69 trees/ha at least $12 \mathrm{~cm} \mathrm{DBH}$ (poles), and 25 trees/ha at least $29 \mathrm{~cm} \mathrm{DBH}$ (sawtimber). This translates to an average spacing of $\approx 12$ and $20 \mathrm{~m}$, respectively. Sixteen years following seed cutting, the widely-spaced residual seed trees remained in place, averaging $8 \mathrm{~m}^{2}$ of BA/ ha at that time (percent canopy cover was not measured at that time). Stand I was part of a 61 ha management block treated as a single unit. Of the 216 systematically located permanent regeneration plots, $168(78 \%)$ occurred off the skid trails. We used these for the analysis. Partial samples were taken at ages 5, 9, and 16. At those dates 45, 40, and 83 of the plots were tallied, respectively.

Stand II is 4 ha and was sampled 13 and 20 years following treatment. Seed cutting during the winter of 1975-1976 left predominantly sugar maple trees, with a residual canopy cover of $\approx 58 \%$ two years after seed cutting. At 14 years, the stand had 190 trees/ha at least $12 \mathrm{~cm} \mathrm{DBH}$, and 54 trees/ha at least $29 \mathrm{~cm}$ DBH. This translated to an average spacing of $\approx 7$ and $13 \mathrm{~m}$, respectively. Twenty years following seed cutting the residual overstory remained in place, averaging $15 \mathrm{~m}^{2}$ of BA/ha at that time (percent canopy cover was not measured at that time). The study site was part of a 36 ha management block treated as a single unit. Forty-seven systematically located permanent regeneration plots occurred within the inter-trail spaces.

Stand III was divided into three blocks, each 3 ha in size. All blocks were sampled at 14, 19, and 26 years following treatment. Seed cutting during the winter of 1968-1969 left primarily sugar maple trees with residual canopy cover of $64 \%$ at 10 years, when it was removed. Stand III was part of a 134 ha management block treated as a single unit. Of the 120 permanent sample plots, 110 (92\%) located off the skid trails were used for the analysis. 
Permanent regeneration plots were systematically located within each of the study stands. Plots landing on major skid trails, large rocks or ponded water were either relocated (Stand II) or excluded from the analysis (stands I and III). Earlier assessments indicated that these microsites commonly fail to regenerate (Kelty and Nyland, 1981; Walters and Nyland, 1989) and that the proportion of total area in skid trails varies widely by stand. By dropping these plot locations, the observations reflect cohort development within the inter-trail spaces, where surface conditions would not preclude regeneration establishment.

Regeneration was tallied by species for total stems (stems $\geq 0.3 \mathrm{~m}$ tall), and by species and diameter for saplings (stems $\geq 2.54 \mathrm{~cm} \mathrm{DBH).} \mathrm{Since} \mathrm{seed} \mathrm{cutting}$ left primarily large-diameter residuals, the regeneration tally includes only trees that established following treatment. Saplings were measured to the nearest $0.01 \mathrm{~cm}$ (except for measurements through year 9 in Stand I and for year 14 in Stand III, when saplings were simply counted). We used $1.13 \mathrm{~m}$ radius (0.0004 ha) regeneration plots through year 9 in Stand I and through year 14 in Stand III. Plot size was increased over time to stabilize variation in stem counts between plots. The original $1.13 \mathrm{~m}$ radius plots were increased to $2 \mathrm{~m}$ radius ( $0.001 \mathrm{ha}$ ) plots at ages 13 or 14 following treatment.

This study takes no direct account of woody species not capable of attaining overstory positions [e.g. witch hobble (Viburnum alnifolium) and elderberry (Sambucus spp.)], and their presence is not reflected in the analyses. None of these species occurred at sufficient density to have noticeable effects within these regenerating stands.

\subsection{Analysis}

Data from the three stands provide an overlapping chronosequence of early cohort development through 26 years following shelterwood seed cutting: from 4 to 16 years in Stand I, from 13 to 20 years in Stand II, and from 14 to 26 years in Stand III. In stands I and II, the seed trees have been retained as an evaluation of reserve shelterwood method. They will eventually provide long-term examples of the manner in which two-aged northern hardwood communities develop. Yet in both cases the seed trees are widely spaced and the new cohort remains well illuminated from above.
Initially, mean stem counts were plotted against time separately by size class for all stands and blocks combined. These plots suggested a common trend in regeneration behavior among stands. However, formal statistical tests to justify integrating the data were complicated both by the limited overlap in remeasurement intervals between stands and by changes in the nature of the response curve (e.g. ingrowth was an increasing function in the youngest stand and a decreasing function in the oldest).

Analysis of variance and mean separation procedures were conducted on log-transformed (plot-level) stem counts to identify significant differences between blocks for total stems and saplings at each measurement period in Stand III. A log transformation on the dependent variable was required to satisfy the assumptions of this analysis. Results revealed no significant differences between blocks within Stand III, so these data were pooled.

Dummy variable analysis was used to test the similarity of regression lines and justify pooling of stand-level data. This procedure is appropriate where a single model can describe the line segments being compared. In our case, plots of the data indicated that stem counts for all size classes made transitions from increasing to decreasing functions over time. With one exception, the amount of overlap in measurements between stands did not adequately incorporate these transitions within a single model. Log-transformation of total stems allowed a comparison among truncated line segments (Stand I years 9 to 16, Stand II - years 13 to 20, and Stand III - years 14 to 19) by this methodology. Results revealed no significant differences among the regressions developed for the three stands, even though they had different degrees of overstory cover through the sampling period. Available data for the sapling class did not permit these formal testing procedures. Justification for modeling the development of the sapling size class was informal, based primarily on the recognition of consistent trends in the data. Analyses were conducted using SAS (SAS Institute Inc., 1990).

A composite model depicting changes in stem densities over time was developed using non-linear regression techniques. Total stems and saplings were modeled with the same equation, using time since treatment as the only predictor variable (Ratkowsky, 
Table 1

Summary of non-linear model parameters by size group for the stand development chronosequence following shelterwood seed cutting at Huntington Wildlife Forest: Stem density $=\operatorname{time}^{a} \exp ^{(b-c * \text { time })}$.

\begin{tabular}{|c|c|c|c|c|c|c|}
\hline \multirow[t]{2}{*}{ Parameter } & \multicolumn{3}{|c|}{ Total stems $($ stems $>0.3 \mathrm{~m}$ tall $)$} & \multicolumn{3}{|c|}{ Saplings (stems $>2.54 \mathrm{~cm} \mathrm{DBH})$} \\
\hline & Estimate & Asymptotic SE & Pseudo $R^{2}\left(\mathrm{SS}_{\mathrm{reg}} / \mathrm{SS}_{\mathrm{tot}}\right)$ & Estimate & Asymptotic SE & Pseudo $R^{2}\left(\mathrm{SS}_{\mathrm{reg}} / \mathrm{SS}_{\mathrm{tot}}\right)$ \\
\hline$a$ & 1.41 & 0.37 & & 5.50 & 1.53 & \\
\hline$b$ & 10.41 & 0.39 & 0.99 & -2.56 & 2.91 & 0.98 \\
\hline$c$ & 0.25 & 0.04 & & 0.26 & 0.08 & \\
\hline
\end{tabular}

1990):

$$
Y=X^{a} \mathrm{e}^{(b-c X)}
$$

where $Y$ is stem density, $X$ the time since treatment, e the base of the natural logarithm, and $a, b$ and $c$ the estimated regression parameters. Trials with several different models suggested that Eq. (1) best represented our data. Means were determined at the stand level, and those values were used to estimate model parameters (Table 1). Residuals were normally distributed for both regressions. Pseudo $R^{2}$ values, given by SSR/SST, where SSR is the sum of squares accounted for by the regression and SST is the uncorrected total sum of squares, were calculated for both regressions. By those criteria, our results indicate these models provide a good fit for the data (Table 1).

\section{Results}

\subsection{Stem density}

Available data were used to characterize the first quarter century of cohort development following shelterwood seed cutting in three Adirondack northern hardwood stands. Observations from Stand I depict the earliest stages of cohort development (Table 2). Total stems were most abundant at year 5. Stem counts remained high through age 9 (89000/ha in Stand I), but by ages 13 (42 000/ha in Stand II), and 14 (46 000/ ha in Stand III) had declined markedly. Sixteen years following seed cutting (29000/ha in Stand I), average stem counts had declined further. Between ages 19 (22 000/ha in Stand III) and 20 (13000/ha in Stand II) and age 26 (11 000/ha in Stand III), the rate of decline in numbers of stems appeared to slow (Fig. 1).

Sapling ingrowth was appreciable by age 9 (900/ha in Stand I) (Table 2). By ages 13 (3600/ha in Stand II), and 14 (4200/ha in Stand III), numbers had increased substantially. Through ages 16 (5800/ha in Stand I) and 19 (6300/ha in Stand III), sapling abundance continued to increase. The 26 year remeasurement (5800/ha in Stand III) suggested that saplings had begun to decline by that time. The model (Fig. 2) reflects this pattern, indicating that saplings were most abundant $\approx 22$ years after seed cutting.

Table 2

Numbers of stems per hectare by stand (means and standard errors) following shelterwood seed cutting at Huntington Wildlife Forest.

\begin{tabular}{|c|c|c|c|c|c|c|}
\hline \multirow[t]{2}{*}{ Stand } & \multirow[t]{2}{*}{ Time } & \multirow[t]{2}{*}{$n$ (plots) } & \multicolumn{2}{|c|}{ Total stems $(\geq 0.3 \mathrm{~m}$ tall $)$} & \multicolumn{2}{|c|}{ Saplings $(\geq 2.54 \mathrm{~cm} \mathrm{DBH})$} \\
\hline & & & Mean thousands & SE thousands & Mean thousands & SE thousands \\
\hline I & 4 & 168 & 85 & \pm 6 & 0.0 & \pm 0.0 \\
\hline I & 5 & 45 & 99 & \pm 10 & 0.1 & \pm 0.1 \\
\hline I & 7 & 169 & 82 & \pm 4 & 0.04 & \pm 0.03 \\
\hline I & 9 & 40 & 89 & \pm 10 & 0.9 & \pm 0.4 \\
\hline II & 13 & 47 & 42 & \pm 4 & 3.6 & \pm 0.4 \\
\hline III & 14 & 110 & 46 & \pm 3 & 4.2 & \pm 0.4 \\
\hline I & 16 & 83 & 29 & \pm 1 & 5.8 & \pm 0.4 \\
\hline III & 19 & 110 & 22 & \pm 1 & 6.3 & \pm 0.3 \\
\hline II & 20 & 47 & 13 & \pm 1 & 4.7 & \pm 0.4 \\
\hline III & 26 & 110 & 11 & \pm 1 & 5.8 & \pm 0.3 \\
\hline
\end{tabular}




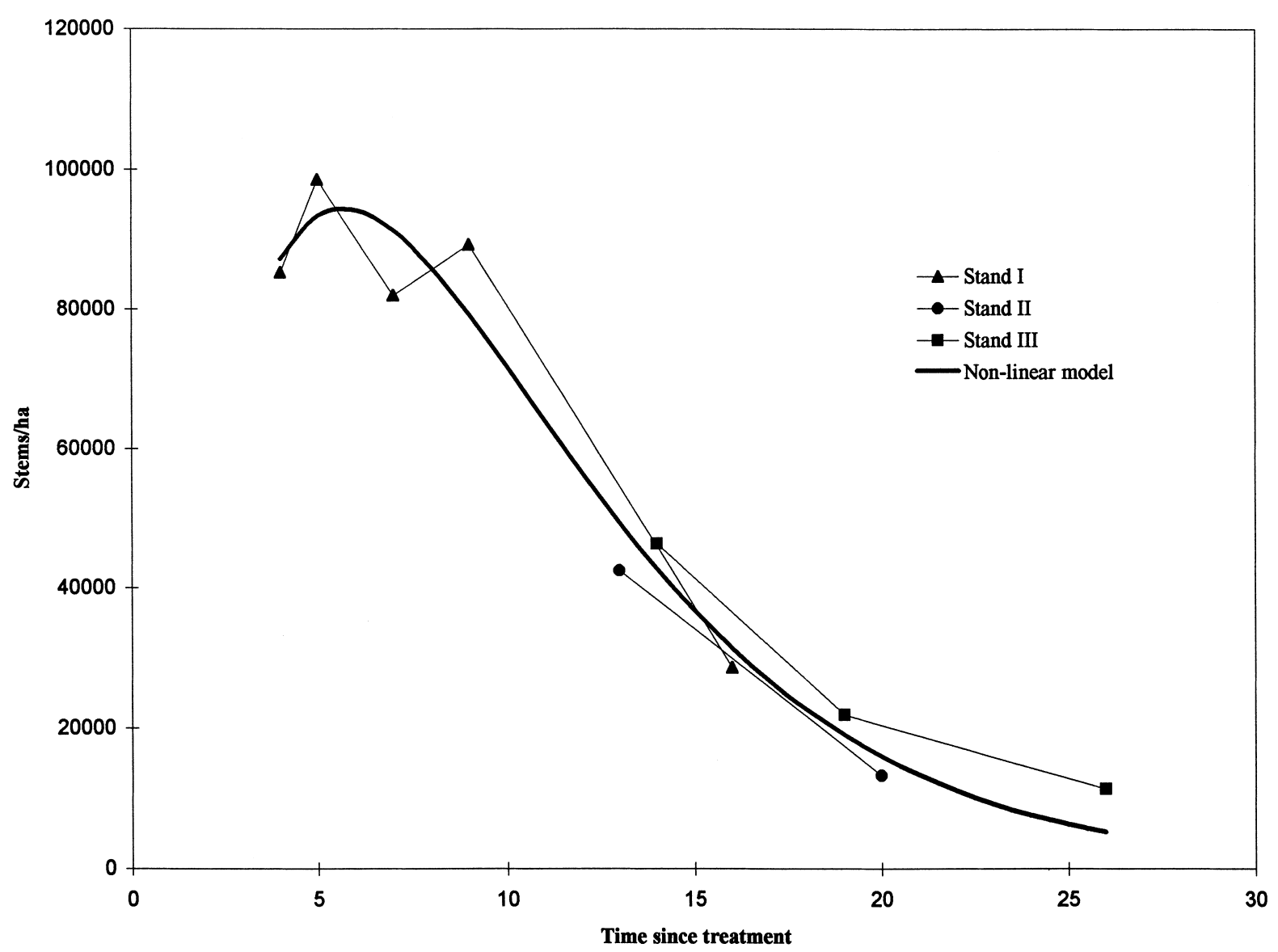

Fig. 1. Total stems $(\geq 0.3 \mathrm{~m}$ tall) as a function of time after shelterwood seed cutting. Stand means are plotted along with the non-linear model.

\subsection{Stocking}

Stocking criteria provide a means for assessing the distribution of growing stock across the regeneration area. Individual plots were considered stocked if they contained at least one stem meeting the given measurement criteria (stems $\geq 0.3 \mathrm{~m}$ tall or $\geq 2.54 \mathrm{~cm}$ $\mathrm{DBH})$. At the time of first measurement, four years following seed cutting in Stand I, $100 \%$ of the 0.0004 ha regeneration plots had at least one tree $\geq 0.3 \mathrm{~m}$ tall (total stems). By age 16 , over $95 \%$ of the 0.0001 ha plots contained at least one sapling $(\geq 2.54 \mathrm{~cm} \mathrm{DBH})$. Thirteen years following seed cutting in Stand II, $100 \%$ of the 0.001 ha plots were stocked with total stems, while saplings were present on over $90 \%$. By age 20, over $95 \%$ of plots were stocked with at least one sapling. At age 14 in Stand III saplings were present on $\approx 75 \%$ of the 0.0004 ha regeneration plots. By age 19, nearly $100 \%$ of 0.001 ha plots were stocked with at least one sapling. Sapling stocking remained near $100 \%$ through age 26 on the 0.001 ha plots in Stand III.

\subsection{Basal area and diameter development}

Saplings were used to describe cohort development in terms of diameter and basal area (BA). Saplings were first measured in Stand I at age 16, when stand BA averaged $8.6 \mathrm{~m}^{2} /$ ha (Table 3). Yellow birch was the most abundant species, contributing $70 \%$ of total stand BA. 'Other' species, primarily pin cherry, accounted for most of the remainder (27\%). The quadratic stand diameter (QSD), given by the diameter of the sapling of mean BA, was $4.4 \mathrm{~cm}$. 


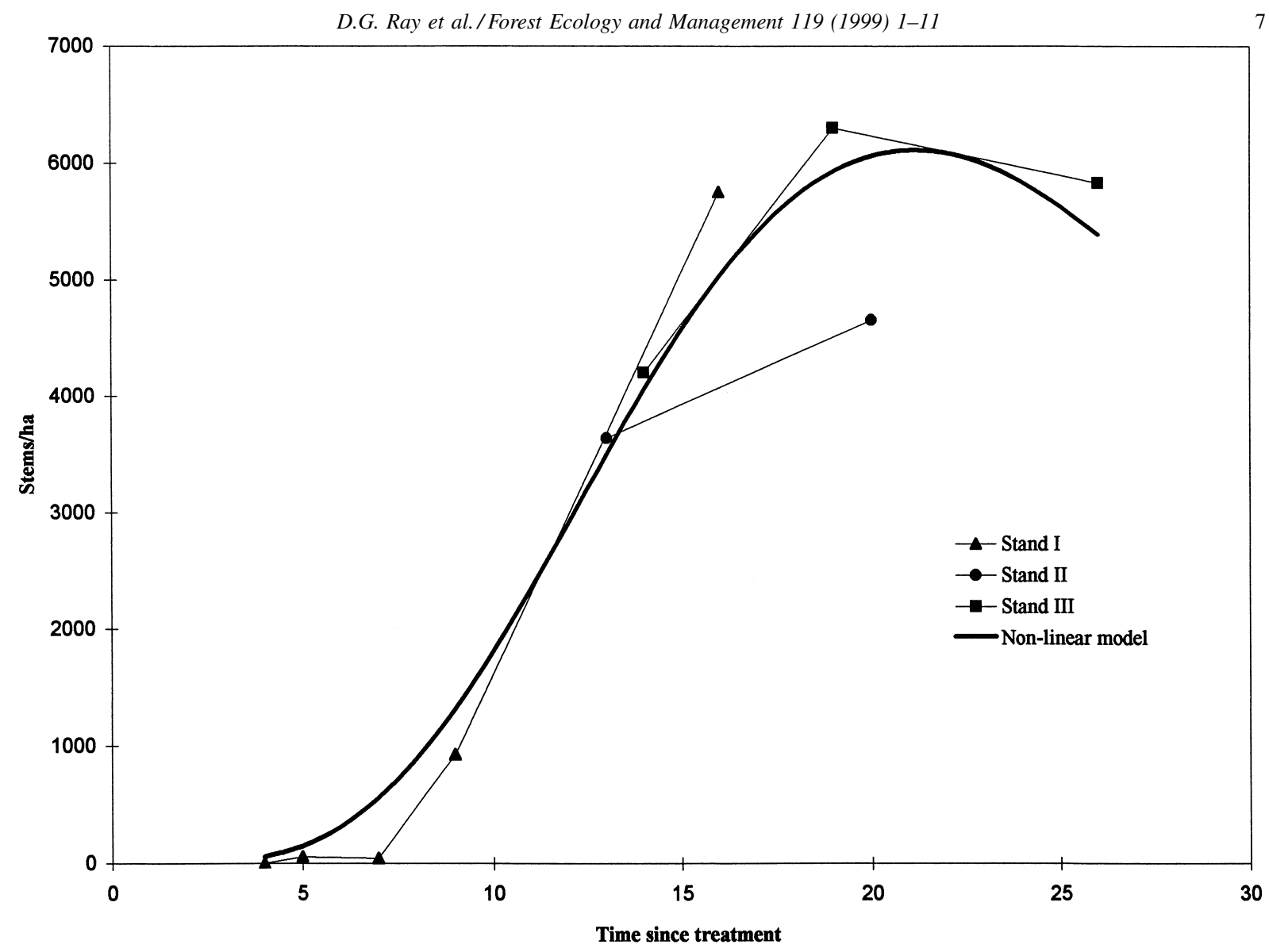

Fig. 2. Saplings $(\geq 2.54 \mathrm{~cm} \mathrm{DBH})$ as a function of time after shelterwood seed cutting, stand means are plotted along with the non-linear model.

Table 3

Sapling ( $\geq 2.54 \mathrm{~cm} \mathrm{DBH})$ basal area (BA) of commonly occurring species in each of the three shelterwood stands at Huntington Wildlife Forest.

\begin{tabular}{|c|c|c|c|c|c|}
\hline Species & $\begin{array}{l}\text { Stand } \mathrm{I}-\text { age } 16 \\
\text { BA }\left(\mathrm{m}^{2} / \mathrm{ha}\right)\end{array}$ & $\begin{array}{l}\text { Stand II - age } 13 \\
\text { BA }\left(\mathrm{m}^{2} / \mathrm{ha}\right)\end{array}$ & $\begin{array}{l}\text { Stand II - age } 20 \\
\text { BA }\left(\mathrm{m}^{2} / \mathrm{ha}\right)\end{array}$ & $\begin{array}{l}\text { Stand III - age } 19 \\
\text { BA }\left(\mathrm{m}^{2} / \mathrm{ha}\right)\end{array}$ & $\begin{array}{l}\text { Stand III - age } 26 \\
\text { BA }\left(\mathrm{m}^{2} / \mathrm{ha}\right)\end{array}$ \\
\hline Beech & 0.07 & 1.44 & 1.74 & 1.87 & 4.65 \\
\hline Sugar maple & 0.09 & 1.47 & 2.87 & 2.74 & 4.31 \\
\hline White ash & 0.06 & 0.80 & 1.59 & 0.36 & 0.96 \\
\hline Yellow birch & 6.07 & 0.36 & 1.16 & 6.94 & 9.66 \\
\hline Other $^{a}$ & 2.30 & 0.87 & 1.41 & 2.95 & 4.33 \\
\hline Total & 8.59 & 4.94 & 8.77 & 14.86 & 23.91 \\
\hline
\end{tabular}

a'Other species: Basswood, aspen, black cherry, eastern hophornbeam, pin cherry, red maple, red spruce, striped maple, white birch and willow.

At age 13 in Stand II, sapling BA averaged $4.9 \mathrm{~m}^{2} /$ ha, with a QSD of $4.2 \mathrm{~cm}$ (Table 3). By age 20, sapling BA was $8.8 \mathrm{~m}^{2} /$ ha and the QSD had increased slightly to $4.9 \mathrm{~cm}$. Over that period, BA increment averaged $0.6 \mathrm{~m}^{2} /$ ha/year. Twenty years after seed cutting, sugar maple accounted for $33 \%$ of stand BA, while beech, 
white ash, and yellow birch each contributed between 13 and $20 \%$ of total stand BA.

In Stand III, sapling BA increased from $14.9 \mathrm{~m}^{2} / \mathrm{ha}$ at age 19 to $23.9 \mathrm{~m}^{2} /$ ha by age 26 , for a seven year average of $1.3 \mathrm{~m}^{2} / \mathrm{ha}$ (Table 3). Over that same period, stand QSD rose from 5.5 to $6.7 \mathrm{~cm} \mathrm{DBH}$. Yellow birch was the most abundant species, accounting for $40 \%$ of stand BA at age 26 . Beech and sugar maple combined accounted for $31 \%$ of stand BA at that time.

\subsection{Effects of the residual overstory}

Shelterwood method prescribes removal of the seed trees when sufficient numbers of desirable seedlings become established and no longer benefit from protective cover. Past research conducted at the Huntington Wildlife Forest suggests that requisite conditions tend to develop by $2-10$ years following seed cutting in these communities (Kelty and Nyland, 1981). By the end of one decade all three stands had sufficient numbers of free-to-grow trees (>12 350/ha). Yet overstory removal has taken place only in Stand III. Seed trees were retained in the other stands to serve other research objectives. Yet if retention of the seed tress in stands I and II had significantly affected the development of the new cohort, the new trees should have noticeably lower heights and the stands should exhibit lower stocking of the less shade-tolerant species. Contrary to this, data gathered from Stand I at age 16 indicated that dominant trees of the new cohort were consistently between 8 and $10 \mathrm{~m}$ tall. Total heights exceeded $10 \mathrm{~m}$ in stands II (age 20) and III (age 26). Proportions of total stems of the less shadetolerant species were 48,15 , and $25 \%$ in stands I, II, and III, respectively. In stands I and II the less shadetolerant saplings largely maintained their status over time (Table 3). Data collected from Stand II at age 2 and Stand III at age 10 (Kelty, 1979) indicated the species composition of these areas also remained fairly uniform over time. In combination, this evidence suggests that shade from the widely spaced reserve trees in stands I and II had not profoundly affected development of the new age class for up to 20 years after seed cutting.

The seed trees in Stand III were removed at age 10. Logging broke off or uprooted regeneration on $25 \%$ of the plots. Subsequent recovery to near full stocking largely resulted from resprouting of damaged stems (Kelty and Nyland, 1981).

\section{Discussion}

Data from the research demonstrate that shelterwood seed cutting in conjunction with the control of interfering vegetation and herbivores successfully regenerated old-growth northern hardwood stands at the Huntington Wildlife Forest in New York's Adirondack Mountains. In fact, a single discernible pattern of cohort development emerged for both total stems ( $\geq 0.3 \mathrm{~m}$ tall) and saplings $(\geq 2.54 \mathrm{~cm} \mathrm{DBH})$ across these northern hardwood communities. The overall pattern of development appears to be the same for stands with and without overstory removal by age 10 years. This finding likely reflects the wide spacing between reserve trees in stands I and II.

The chronosequence developed from the three stands indicates that total stems were most abundant approximately five years after seed cutting. By contrast, work in other areas has indicated that total stem densities and species diversity may peak between two and four years following an even-aged regeneration cutting (Bormann and Likens, 1981; Hibbs, 1983; Metzger and Schultz, 1984; Marquis, 1987). The delay in tree community reorganization at Huntington Wildlife Forest most likely reflects the absence of advance regeneration due to the understory herbicide treatment used to prepare the site before seed cutting.

Periodic seed shed by mature trees often results in ephemeral flushes of small seedlings that do not persist in the understory of developing even-aged communities. In managed northern hardwood stands in upper Michigan, numbers of seedlings $<0.5 \mathrm{~m}$ tall fluctuated substantially from year to year (Metzger and Schultz, 1984). In Pennsylvania similar variability was attributed to periodic seed shed by the residual shelterwood overstory, and subsequent seedling mortality (Horsley and Marquis, 1983). Like patterns were observed in the recently regenerated Huntington Wildlife Forest stands where the seed trees remained in place. Thus, to minimize the effect of these ephemeral pulses on model predictions, we defined total stems as those $\geq 0.3 \mathrm{~m}$ tall.

Observations in the three stands described here, in stands on the Allegheny plateau in central New York 
(Walters and Nyland, 1989), and in southeastern British Columbia (Oswald and Brown, 1993) document only limited establishment and growth of free regeneration on main skid trails. Also, the proportion of area allocated to skid trails varies from one stand to another without a consistent pattern. Thus, by eliminating advance regeneration through understory mistblowing treatments, and omitting the plots located on skid trails, the findings point to a baseline for stocking following commercially implemented shelterwood seed cutting.

Consistent with findings of Kelty and Nyland (1981) and Walters and Nyland (1989), stem counts within the inter-trail space did not decline substantially over the first decade of even-aged stand development. Rubus is typically dominant early in the regeneration period following even-aged reproduction method cutting, at least until trees grow up above it in sufficient numbers to begin forming a closed canopy. Our data indicate that between ages 7 and 9, many trees had grown to above $2 \mathrm{~m}$ tall and began to overtop the Rubus. Thereafter, that species declined in abundance and dominance.

Findings from other research indicate the first wave of mortality in a young cohort can be quite distinct (Oliver and Larson, 1996). Similarly, our model for total stems (Fig. 1) in the Huntington Wildlife Forest shelterwood stands indicates a substantial reduction in stem counts between ages 9 and 13. This supports earlier research, indicating that crown closure had occurred by about that time, and the trees had begun to stratify into discernable crown classes (Wang and Nyland, 1993).

Only limited amounts of ingrowth into the sapling size class were observed over the first decade of cohort development. Sapling abundance increased substantially beyond age 10 , with the model suggesting a slowing of sapling ingrowth between ages 15 and 20, and a declining trend beyond that point (Fig. 2). By age 26, all stems in main canopy positions were saplings, whereas at ages 16 (Stand I) and 20 (Stand II) only 44 and $67 \%$, respectively, had grown that large.

Using total stems and saplings as stocked-plot criteria, and considering only plots located within the inter-trail spaces, nearly $100 \%$ of plots were stocked with at least one qualifying stem during the study period. Total stems were well represented by age
4, and saplings by age 14 (stands I and II, respectively). These data indicate when a relatively homogeneous spatial distribution of stems, by size class, was attained in these stands. Among all saplings at age 20 (Stand II), 69\% were commercial species, yet $81 \%$ of plots were stocked with at least one stem of these preferred species. At age 26 (Stand III), only 66\% of all saplings were commercially desirable, but $99 \%$ of plots were stocked with at least one commercially valuable stem. However, since we did not classify stems by crown position, our stocking assessment likely provides an overly optimistic view of those conditions. Past research has indicated that shifts in species dominance occur during cohort development, with a tendency towards eventual site dominance by the longer lived species (Horn, 1975; Bormann and Likens, 1981; Hibbs, 1983; Wang and Nyland, 1993; Arthur et al., 1997). Our data appear consistent with those earlier findings.

Over time, self-thinning reduces the total number of trees in even-aged stands at high levels of relative density. At the same time, BA increases towards a 'type-specific' maximum level over time. Consistent with various general development models (Bormann and Likens, 1979; Oliver, 1981), basal area increased in a consistent pattern across the stands. Yet the magnitude of change differed, particularly between stands II and III (Table 3). Stand III had a higher BA at age 19 than Stand II at age 20. Stand I was intermediate to the others at age 16 . These differences likely reflect a variation in species composition within the new cohort, in that stands I and III had the highest proportion of basal area in intermediate and shadeintolerant species. These at least initially grew more rapidly than the sugar maple and beech. The overall pattern of BA development is consistent with the concept of maximum relative density, where undisturbed even-aged stands in a given forest type tend to follow a common trajectory of development (Gingrich, 1967; Leak et al., 1969; Roach, 1977; Stout and Nyland, 1986). The effect of processes that regulate stand density is evidenced by the similarity in numbers of stems among blocks over time within Stand III. Perhaps more important, our success at modeling patterns of development across the three stands supports the idea that these patterns are robust across a range of overstory residual densities and species compositions within the new cohort. 
Canopy closure precedes self-thinning in undisturbed single-cohort stands. Accepted hypotheses suggest that horizontal canopy coverage remains relatively stable following canopy closure, at least early in the aggradation period (White, 1981; Long and Smith, 1984; Zeide, 1991). If we assume that canopy closure occurred around year 10 in these cohorts, and that this led to stratification and selfthinning, then the composite model presented for total stems (Fig. 1) portrays the maximum level of stocking (in terms of numbers of stems) beyond that point. Yet, since the shade-tolerant species can persist in subordinate crown positions, and shade-intermediate species may succumb somewhat slowly to competition as stratification progresses, the composite model depicting development of the sapling size class (Fig. 2) may provide an accurate depiction of the self-thinning processes occurring within the main crown canopy of the emerging cohort. This would certainly be the case by 15 or 20 years following seed cutting in these stands. Interestingly, since two of the stands have a relatively low density of older seed trees still in place, the development model presented here may also serve as a useful interim guide for early stages of development within the young cohort of a two-aged community of northern hardwoods.

Overall, shelterwood cutting in old-growth Adirondack northern hardwoods on the Huntington Wildlife Forest produced a consistent pattern of development in the numbers and sizes of trees in the new cohort over time. The regression models presented here should provide a reasonable estimate of stand conditions during the first quarter century of cohort development following even-aged reproduction method cutting in this forest type.

\section{Conclusions}

Data gathered for this study and the resulting regression equations depict early development of recently regenerated northern hardwoods through 26 years following shelterwood seed cutting, with and without overstory removal. Equations indicate the numbers and sizes of trees that managers can expect to find at different times after seed cutting preceded by control of interfering woody understory and deer density. They serve as useful functions for modeling those conditions in emerging northern hardwood communities following similar treatments.

Competitive interactions between species often lead to common patterns of development within a forest type (Oliver and Larson, 1996). Our findings indicate that these shelterwood stands have moved along a common trajectory. Total stems peaked at around age 5 , suggesting that few new individuals became established after that time. Total stems declined substantially thereafter, indicating that crown closure had led to stratification and high levels of mortality. The model suggests that saplings had peaked by age 22 , and began to decline by age 26 . The approach of using a combination of chronosequence and remeasurement data, as employed in this study, appears suitable for modeling long-term response functions in forestry.

\section{Acknowledgements}

This research was supported by USDA Forest Service in conjunction with the development of the Northeast Decision Support Tools (NED), and the Mcintire-Stennis Cooperative Forestry Research Program.The authors gratefully acknowledge the helpful suggestions of Mark J. Twery, Russell D. Briggs, Lianjun Zhang, Christopher A. Nowak, Daniel W. Gilmore, and Susan L. Stout for reviews of the manuscript. Also, we thank the staff at the Huntington Wildlife Forest for their support during the field season.

\section{References}

Arthur, M.A., Muller, R.N., Costello, S., 1997. Species composition in a central hardwood forest in Kentucky 11 years after clear-cutting. Am. Midl. Na. 137, 274-281.

Bormann, F.H., Likens, G.E., 1979. Catastrophic disturbance and the steady state in northern hardwood forests. Amer. Sci. 67, 660-669.

Bormann, F.H., Likens, G.E., 1981. Pattern and Process in a Forested Ecosystem. Springer-Verlag, New York, p. 253.

Gingrich, S.F., 1967. Measuring and evaluating stocking and stand density in upland hardwoods. U.S. For. Serv. Res. Pap. NE-195.

Hannah, P.R., 1988. The shelterwood method in Northeastern forest types: a literature review. N.J. Appl. For. 5, 70-77.

Hibbs, D.E., 1983. Forty years of forest succession in central New England. Ecol. 64, 1394-1401.

Horn, H.S., 1975. Forest succession. Sci. Amer. 232, 90-98. 
Horsley, S.B., Marquis, D.A., 1983. Interference by weeds and deer with Allegheny hardwood regeneration. Can. J. For. Res. 13, 61-69.

Horsley, S.B., 1994. Regeneration success and plant species diversity of Allegheny hardwood stands after Roundmap application and shelterwood cutting. North. J. Appl. For. 11(4), 109-116.

Kelty, M.J., 1979. Use of Shelterwood Method for Regenerating Northern Hardwoods and Influencing Deer Browse. M.S. thesis. State Univ. of New York, Coll. Environ. Sci. and For., Syracuse, NY.

Kelty, M.J., Nyland, R.D., 1981. Regenerating Adirondack northern hardwoods by shelterwood cutting and control of deer density. J. For. 79, 22-26.

Kelty, M.J., 1987. Shelterwood cutting as an even-aged reproduction method. In: Nyland, R.D. (Ed.), Managing Northern Hardwoods. A Silvi. Sympos., 23-25 June 1986, SUNY Coll. Environ. Sci. and For., Syracuse, NY. SUNY-ESF Fac. For. Misc. Publ. 13 (ESF 87-002) (Soc. Am. For. Publ. 87-03).

Leak, W.B., Solomon, D.S., Filip, S.M., 1969. A silvicultural guide for northern hardwoods in the Northeast. U.S. For. Serv. Res. Pap. NE-143.

Long, J.N., Smith, F.W., 1984. Relations between size and density in developing stands: a description and possible mechanism. For. Ecol. and Manage. 7, 191-206.

Marquis, D.M., 1987. Assessing the adequacy of regeneration and understanding early development patterns. In: Nyland, R.D. (Ed.), Managing Northern Hardwoods. A Silvi. Sympos., 23-25 June 1986, SUNY Coll. Environ. Sci. and For., Syracuse, NY. SUNY-ESF Fac. For. Misc. Publ. 13 (ESF 87-002) (Soc. Am. For. Publ. 87-03).

Marquis, D.A., Ernst, R.L., Stout, S.L., 1984. Prescribing silviculture treatments in hardwood stands of the Alleghenies. US For. Serv. Gen Tech. Rep. NE-96.

Metzger, F.T., Schultz, J., 1984. Understory response to 50 years of management of a northern hardwood forest in upper Michigan. Am. Midl. Nat. 112(2), 209-223.

Oliver, C.D., 1981. Forest development in North America following major disturbances. For. Ecol. and Manage. 3, 153168.

Oliver, C.D., Larson, B.C., 1996. Forest Stand Dynamics: Update edition. John Wiley and Sons. NY, p. 520.
Ostrofsky, W.D., McCormack, M.L., Jr., 1986. Silvicultural management of beech and the beech bark disease. In: Nyland, R.D. (Ed.), Managing Northern Hardwoods. A Silvi. Sympos., 23-25 June 1986, SUNY Coll. Environ. Sci. and For., Syracuse, NY.

Oswald, E.T., Brown, B.N., 1993. Vegetation development on skid trails and burned sites in southeastern British Columbia. For. Chron. 69(1), 75-80.

Ratkowsky, D.A., 1990. Handbook of Nonlinear Regression Models. Marcel Dekker, Inc., New York, p. 241.

Richards, N.A., Farnsworth, C.E., 1971. Effects of cutting level in regeneration of northern hardwoods protected from deer. J. For. 69, 230-233.

Roach, B.A., 1977. A stocking guide for Allegheny hardwoods and its use in controlling intermediate cuttings. U.S. For. Serv. Res. Rep. NE-373.

Roach, B.A., Gingrich, S.F., 1968. Even-age silviculture for upland central hardwoods. US Dep. Agr. Handbk, p. 355.

Sage, D.W., 1983. An Evaluation of Several Herbicides Used for Site-Preparation in Northern Hardwood Stands. M.S. thesis. State Univ. of New York, Coll. Environ. Sci. and For., Syracuse, NY.

SAS Institute Inc., SAS/STAT User's Guide, Version 6, fourth edn., volumes 1 \& 2, Cary, NC: SAS Institute Inc., 1990.

Simon, S.A., 1979. Vegetation Classification and Assessment of Forest Productivity in the Adirondacks. M.S. thesis. State Univ. of New York, Col. For., Syracuse, NY.

Stout, S.L., Nyland, R.D., 1986. Role of species composition in relative density measurement in Allegheny hardwoods. Can. J. For. Res. 16, 574-579.

Tierson, W.C., 1967. Influence of logging, beech control, and partial deer control on northern hardwood reproduction. M.S. thesis. State Univ. of New York, Coll. Environ. Sci. and For., Syracuse, NY.

Walters, R.S., Nyland, R.D., 1989. Clearcutting central New York northern hardwood stands. N.J. Appl. For. 6(2), 75-79.

White, J., 1981. The allometric interpretation of the self-thinning rule. J. Theo. Bio. 89, 475-500.

Zeide, B., 1991. Self-thinning and stand density. For. Sci. 37, 517523.

Wang and Nyland, 1993. Tree species richness increased by clearcutting of northern hardwoods in central New York. For. Ecol. and Manage. 57, 71-84. 